\title{
A Comparative Study between Chinese and English News Leads
}

\author{
Shan Liu \\ School of Foreign Languages \\ Wuhan Textile University \\ Wuhan, China \\ e-mail: susanliu212@126.com
}

\begin{abstract}
Based on the studies of news lead and cultural differences, this paper studies commonnesses and differences between Chinese and English news leads in three aspects: grammatical structures, writing styles and six elements and explores the causes, through the establishment of small corpus composed of fifty Chinese and English news leads, with quantitative and qualitative method.
\end{abstract}

Keywords-news lead; difference; cultural

\section{INTRODUCTION}

Lead is an important symbol of news, which is different from other genres. It is not used to introduce a cause of event, or not just to play a guiding role. From the format's point of view, it is generally the first paragraph of the message or the opening paragraphs; from the content's point of view, it must generalize the news events with concise language; from the function's point of view, it should concentrate on the events to extract and show the freshest, most important and attractive part of news, forming a power which attract audients with first glance. In short, lead is the core of message, the eye of news. The quality of lead is directly related to the promotional effect of news. Western journalists pay great attention to the role of lead, as it as the essence of the news, and it's also the showing a reporter literary talent.

Generally, lead has three functions. First, leads go straight to the point, reporting the facts of news as quickly as possible, and delivering the latest information to reader at a glance. Second, leads attract readers, making people "love at the first sight". Third, leads play a guiding role in determining the writing focus and keynote of message.

This study is based on analysis of a corpus, which was postagged and lemmatized with the software TreeTagger, and then was analyzed by Antconc. The 50 selected Chinese leads mainly come from People's Daily, Xinhua news agency and 50 English leads are from CNN、 USA Today and English version of People's Daily, all of which are about the political, economic and social issues.

\section{The COMmon Ground BetweEn EnGlish AND CHINESE LEADS}

Generally, Chinese and English leads have so many commonnesses, because it should contain hereinbefore three characteristics no matter it is written in what language. Besides these characteristics, lead has more basic elements called "5 W" who, what, where, when and why. In other words, they are actor, action, place, time and attribution. The following table shows the presence and absence of each element.

\begin{tabular}{|l|l|l|l|l|}
\hline Elements & \multicolumn{2}{l|}{ No. of Presence } & \multicolumn{2}{l|}{ No. of Absence } \\
\hline & American & Chinese & $\begin{array}{l}\text { America } \\
\mathrm{n}\end{array}$ & Chinese \\
\hline Actor & 50 & 50 & 0 & 0 \\
\hline Action & 50 & 50 & 0 & 0 \\
\hline Time & 46 & 47 & 4 & 3 \\
\hline Place & 50 & 50 & 0 & 0 \\
\hline $\begin{array}{l}\text { Backgro } \\
\text { und }\end{array}$ & 20 & 15 & 30 & 35 \\
\hline Review & 21 & 22 & 29 & 28 \\
\hline
\end{tabular}

From the table we can see the number of actor, action and place presence, which are essential to good leads.

\section{A. Actor}

Actor can be the subject or object in lead, which rests with the journalist's point of view of the event when it happens. But it must exist in the lead to tell a whole thing, and sometimes it becomes the topic to attract more readers.

e.g. 
TOKYO_Japan's prime minister pledged Saturday to accelerate efforts to form a free-trade agreement with China and South Korea, an ambitious pact that could create an integrated trade zone rivaling in size the North American Free Trade Agreement and the European Union. (October 4th, 2009,People's Daily)

据新华社专电 “脸谱” 网站首次公开募股（IP0） 在即，联合创始人之一爱德华多萨韦林“及时”退出美 国国籍，有望为自己省下大笔税金。美国媒体 11 日报 道, 近些年, “脱美” 者增加. (Eduardo Saverin, the billionaire co-founder of Facebook, renounced his US citizenship before the social network's IPO, which would expectedly save a large sum of tax. According to reports of American media on 11th, recent years see an increase of those who renounce their US citizenship ) (May 13th,2012,Xinhua news agency)

Both of the leads' actors are those everyone knows, which attracts readers to read.

\section{B. Action}

The action is the most important part of lead, because everyone reads news in order to know what happened. Both Chinese and English leads are not like titles of news that can put up a question to attract readers' curiosity. The lead's charm is from the brief and accurate fact.

e.g.

BEIJING - China's central bank on Saturday lowered the level of reserves that banks must hold, move to support growth after a spate of date earlier this week revealed weakening economic momentum.

(Dec.4th,2011, People's Daily)

据新华社电 日本学者 11 日警告, 如果出生率继续 下降，依理论推算，一千年后日本人将不复存在。 (Japanese scholars alerted on 11th May that if birth rate's declining trend continued, Japanese would extinct in 1000 years theoretically)

13th,2013,Xinhua news agency)

(May

News stories also contain at least one of the following important characteristics relative to the intended audience: proximity, prominence, timeliness, human interest, oddity, or consequence. The two leads both have attractive matter to catch the readers' attention.

\section{Place}

Usually the reader's mental condition relates to the distance of the event. The closer the distance, the stronger public effect it creates. Readers can get the information of accurate place from news lead to be informed of the situation around them.

e.g.

KABUL---A senior Afghan peace negotiator who once served in the Taliban government was shot dead in Kabul on
Sunday, in yet another blow to attempts to find a negotiated end to the war. (May.3th,2012,CNN)

本报讯（记者 夏琼 通讯员 周凯）你同意热干面、宠 物狗、扁担禁上地铁吗? 众目期待的武汉地铁已经通 车，昨日，市政府法制办公布《武汉市轨道交通管理条 例 (征求意见稿) 》, 明确规定, 在轻轨、地铁上吃热 干面、带宠物狗、扛扁担都将被禁止, 违者将被罚五十 至一百元。 (Do you agree that hot and dry noodles, pets and carrying poles are forbidden to be taken to subway? Wuhan metro, which has been in the spotlight, is open. Office of legislative affairs from Municipal government published The Rule concerning Rail Transmit in Wuhan yesterday, according to which, all the above-mentioned behaviors will be forbidden. Offenders will be fined 50 to 100 yuan.)

(December,10th ,2012,People's Daily)

From the two leads we can see the second lead may be more attractive if you live in Wuhan.

These elements are important parts of news lead, but besides these elements if a journalist intends to write a good lead, he should be equipped with essential linguistic skills.

\section{The DifFERENCES BeTweEn CHINESE AND ENGLISH NEWS LEADS}

\section{A. The differences of Grammatical Structure}

Lead is the soul of news. Sentences of it must have a highdegree capacity and strict structure. In this aspect, Chinese and English leads have their own characteristics.

\section{1) The Differences of Morphology}

English leads always use phrasal verb. The meaning of sentences is close-knit. There are many nouns and prepositions in them, while Chinese leads tend to use clause, and the meaning of sentences are loose with a lot of verbs.

e.g.

Norway's prime minister cannot use his new bomb proof car despite a threat of attack by al Qaeda because Norway's state road authority says it is too heavy, Reuters reported Monday. (Dec.5th, 2012,CNN)

新华社周一报道, 尽管受到基地组织威胁, 挪威 首相还是不能使用他的新防爆炸轿车，因为挪威道路管 理部门称新车太重。(Despite the threat from Qaida, Norway PM still couldn't use his new anti-explosion car because Norway road administration claimed that this new car was overweighed) (May 13th,2013,Xinhua news agency)

This is a simple sentence with many subordinate ingredients, and it can't be expressed by a long simple sentence in Chinese, so it would make Chinese readers puzzled and find it difficult to understand it. Therefore, it should be 
divided into several sense-groups, and expressed by a number of clauses.

The corpus was POS-tagged and lemmatized with the Tree Tagger. The statistic results are as follows. Most words in the main parts of speech in the corpus are nouns, verbs and prepositional phrases, few are adjectives and adverbs. The frequency of noun and verb in both Chinese and English news lead plays the dominating role. Verbs and nouns in the English language are more often used than Chinese. In English news leads, the proportion of verb divided by a noun is 1.5; however, the Chinese is 1.2. e.g.

\begin{tabular}{|c|c|c|}
\hline Times & $\mathrm{n}$. & $\mathrm{V}$. \\
\hline $\begin{array}{l}\text { English news } \\
\text { lead }\end{array}$ & 304 & 200 \\
\hline $\begin{array}{l}\text { Chinese news } \\
\text { lead }\end{array}$ & 242 & 193 \\
\hline
\end{tabular}

2) The Differences of Syntax

English leads are usually written with long complex sentences. On the contrary, Chinese leads always consist of subordinate clauses and infinitive phrases with strict structure, and some leads' sentences are long and have many clauses.

$$
\text { e.g. }
$$

The director general of the World Health Organization, Mr. Halfdan Mahler, yesterday predicted that up to 100 million people world-wide may become infected with the AIDS virus in the next four or five years and that time it would cost at least $\$ 115$ billion a year to counteract the disease, when virus may vary as time goes and become harder to control. (May, $15^{\text {th }}, 2012$, USA Today)

世界卫生组织执行长官 Half dan Mahler 先 生，昨日预言在今后四、五年内全世界将可能有 1 亿人感染艾滋病, 届时, 由于艾滋病毒有可能变 异, 难控制, 每年可能需要投入 15 亿美元来对付 它。(The director of the WHO, Mr Halfdan Mahler, yesterday predicted that up to 100 million people worldwide may become infected with AIDS virus in the next four of five years and by that time it would cost at least \$ 1.5 billion a year to counteract the disease, when virus may vary as time goes and become harder to control.)((May 10th,2012,People's Daily)

Sentence length is the total number of words contained in a complete sentence. In terms of a lead, sentence length is the length of the actual lead. Software "Readability Analyzer" is used to get the English corpus of the average sentence length (ASL). The results are as follows:

\begin{tabular}{|l|l|l|}
\hline Corpus & $\begin{array}{l}\text { Chinese news } \\
\text { lead }\end{array}$ & $\begin{array}{l}\text { English news } \\
\text { lead }\end{array}$ \\
\hline ASL & \multicolumn{2}{|c|}{14.6} \\
\hline
\end{tabular}

As is shown from the above table, average sentences in English news leads are longer than that in Chinese leads.

\section{B. The Use of Passive Voice}

Western journalist often use passive voice writing news lead, especially when they do not know who is the action agent or hope to emphasize the object of the action, while passive voice is not used extensively in Chinese.

e.g.

LIMA, Peru-A cache of fireworks exploded at a shop near a street market in down town Lima, spreading fire through four blocks of apartments and stores. At least 77 people were killed and 115 others injured, the Civil Defense said.

秘鲁利马电一秘鲁首都利马中心一市场的一个 烟花店29日晚发生爆炸, 大火蔓延到附近四个街区 的居民楼和商店, 造成至少 77 人死亡, 115 人受伤。 (February $28^{\text {th }}, 2012$, People's Daily)

This lead focuses on the number of people who were affected, so it uses passive voice to stress the seriousness of event.

\begin{tabular}{|c|c|c|}
\hline & Active voice & $\begin{array}{c}\text { Passive } \\
\text { voice }\end{array}$ \\
\hline $\begin{array}{c}\text { Chinese } \\
\text { news lead }\end{array}$ & 50 & 0 \\
\hline $\begin{array}{c}\text { English } \\
\text { news lead }\end{array}$ & 38 & 12 \\
\hline
\end{tabular}

The above table shows there are not passive voice in Chinese news lead, but English news lead often use passive voice in order to enhance the severity of the event.

\section{Style of Writing}

Chinese lead often begins with relevant information, followed by the subject, which requires readers to understand the implied meaning; on the contrary, English lead clarifies the theme from the very beginning. The first sentences of English lead is always the most important fact of news, and it always comes up with general idea firstly and then gives the specific information to explain details.

e.g.

MANCHESTER,England,Jan29(reporters)-Mike Tyson demolished Julia franchise in a heavyweight mismatch on Saturday, ending the weeks of hype by floor him five in just over four minute. (March 29th,2013,CNN)

3 月 18 日, 山东滨州北海边防大队边防民警在为 孩子们讲解如何识别交通标志。为确保学生交通安 全, 北海边防大队近日开展 “学交规保安全” 活 动。边防民警借助图片资料向辖区小学生讲解交通 安全常识, 让孩子们从小就养成遵守交通规则的好 习惯。

(Policeman of Frontier defense bureau gave children a lecture on how to identify traffic signs at Bingzhou, Shandong Province on 18th, March. Frontier defense bureau of Binghai organized a campaign aimed at 
spreading traffic rules and ensuring safety. They explained traffic rules to primary school students of area under administration with pictures, so that children will get into good habit of obeying traffic rules from childhood.)

(March,18th ,2013,People's Daily)

This English lead gives the general idea first, and then tells the details about the mismatch. These differences can be due to the East-West cultural value orientation. Generally speaking, Chinese are comparatively euphemistic and implicit, and indirectly show their attitude made the readers to think by themselves. In addition, Chinese culture pursues the true nature of things and does not emphasize the internal logical relationship, and things are often arranged in natural facts order. Westerners advocated personality, emphasizing the freedom to express personal point of view, so their articles are often opinionated, direct and clear.

\section{Comparison of the Structure of the Six Elements}

\section{1) Differences of News Event Location}

If the event is at the first $1 / 3$ part of the article, it is considered at the beginning. If in the middle $1 / 3$, it is in the middle. If there is in the last $1 / 3$, it is at the end. However, some material is very short, such as news leads. So if the event appears in the first $1 / 2$, it is at the beginning, and the second $1 / 2$, the end.

The corpus analysis shows $80 \%$ of in English news leads are placed at the beginning in contrast with only $26 \%$ of Chinese news leads at the beginning, which indicates that Americans prefer to put News events at the beginning, who are more inclined to inform the event earlier, contrary to the Chinese people's habit.

\begin{tabular}{|c|c|c|}
\hline Number & $\begin{array}{l}\text { Beginning } \\
(\text { No./\%) }\end{array}$ & $\begin{array}{l}\text { Ending } \\
\text { (No./\% } \\
\text { ) }\end{array}$ \\
\hline $\begin{array}{l}\text { English } \\
\text { lead }(n=50)\end{array}$ & $40 \quad 80 \%$ & $\begin{array}{r}10 \\
20 \%\end{array}$ \\
\hline $\begin{array}{ll}\text { Chinese } & \text { news } \\
\operatorname{lead}(n=50) & \end{array}$ & $13 \quad 26 \%$ & $\begin{array}{r}37 \\
74 \%\end{array}$ \\
\hline
\end{tabular}

2) Different Positions of the Actor in the News

\begin{tabular}{|lc|cc|cc|}
\hline \multicolumn{2}{|c|}{ Number } & \multicolumn{2}{|c|}{ Beginning (No./\%) } & \multicolumn{2}{|c|}{$\begin{array}{l}\text { Ending } \\
\text { (No./\%) }\end{array}$} \\
\hline $\begin{array}{l}\text { English news } \\
\text { lead(n=50) }\end{array}$ & 48 & $96 \%$ & 2 & $4 \%$ \\
\hline $\begin{array}{l}\text { Chinese news } \\
\text { lead(n=50) }\end{array}$ & 45 & $90 \%$ & 5 & $10 \%$ \\
\hline
\end{tabular}

The corpus analysis shows $96 \%$ of actors in English news lead are located at the beginning and $90 \%$ of actors in Chinese news leads at the beginning. From the table we can see that more actors in English news leads than Chinese news lead are placed at the beginning

\section{3) News Background in Different Position}

News background comes before the news event itself. A long background is called as "history". News background plays an important role in the news. The lead all reflect the same social function. News background often appears at the beginning of Chinese news, which is just opposite for English news. The corpus analysis shows $75 \%$ of English news background appears at the end. However, $67 \%$ of Chinese news background shows at the beginning.

\begin{tabular}{|lc|lc|lc|}
\hline \multicolumn{2}{|c|}{ Number } & \multicolumn{2}{|l|}{$\begin{array}{l}\text { Beginning } \\
\text { (No./\%) }\end{array}$} & \multicolumn{2}{|l|}{$\begin{array}{l}\text { Ending } \\
\text { (No./\%) }\end{array}$} \\
\hline $\begin{array}{l}\text { English } \\
\text { lead(n=20) }\end{array}$ & news & 5 & $25 \%$ & 15 & $75 \%$ \\
\hline $\begin{array}{l}\text { Chinese } \\
\text { lead(n=15) }\end{array}$ & new & 10 & $67 \%$ & 5 & $33 \%$ \\
\hline
\end{tabular}

4) News Commentary in Different Position

News comment is often associated with journalists. It contains the personal opinion and outlook to the event development. The comments of news leads are in different positions for Chinese and English news leads. There are $80 \%$ English news lead comments in the beginning, while only $45 \%$ for Chinese news.

\begin{tabular}{|lc|lc|lc|}
\hline \multicolumn{2}{|c|}{ Number } & \multicolumn{2}{|c|}{$\begin{array}{l}\text { Beginning } \\
\text { (No./\%) }\end{array}$} & \multicolumn{2}{c|}{$\begin{array}{c}\text { Ending } \\
(\text { No./\%) }\end{array}$} \\
\hline $\begin{array}{l}\text { English news } \\
\text { lead(n=21) }\end{array}$ & 18 & $80 \%$ & 3 & $20 \%$ \\
\hline $\begin{array}{l}\text { Chinese news } \\
\text { lead(n=22) }\end{array}$ & 10 & $45 \%$ & 12 & $55 \%$ \\
\hline
\end{tabular}

5) The Location of News Source

News source refers to the source of news. News source position is distinct in both Chinese and English news leads. Basically, in English, news sources are usually put in the last part, unless it is important source. But Chinese news sources are usually placed at the beginning of a sentence.

e.g.

ANCHORAGE, Alaska (AP) - An Alaska State Trooper helicopter carrying a trooper, a pilot for the agency and a rescued snowmobiler crashed in the southcentral part of the state, leaving the three aboard feared dead, a spokeswoman said Sunday night. (March 18th,2009,USA Today)

上海 3 月 23 日电 (记者 フ海洋 许婧)中共中央党校 前副校长郑必坚 23 日在上海举行的第五届世界中 国学论坛上称, 中国正在走的大国和平发展道路是 从未有过的, 中国应不断寻找并构建与其他国家的 “利益汇合点”和“利益共同体”。 (Zheng Bijian, former vice president of Party school of the CPC claimed in the fifth World Chinese Forum on 23th in Shanghai that the road of peaceful development that China is on has no precedent, so China is expected to seek for and build "benefit confluence" and "benefit 
community" with other countries.) (March, 23 ${ }^{\text {rd }}$,

Xinhua news agency)

This is due to differences between Chinese and English culture and the people's style of thinking.

\section{CONCLUSION}

As the lead-in of news, lead plays a role of guiding readers to generalize messages. Because of the differences of English and Chinese culture, when we read leads, we should pay attention to these differences, such as semantic structure, syntax, morphology and so on, in order to get more accurate information. Exploration into differences between Chinese and English leads helps us to catch the key information of both languages for the sake of better communicate with others.

\section{REFERENCES}

[1] Berner, R. Thomas. The process of writing news[M].USA: Allyn and Bacon.1992.

[2] Hatim, basil. Communication across cultures: Translation theory and contrastive text linguistics [M]. UK: University Press.1997,123

[3] Van Dijk, T.A 1985.News Schemata. In Greenbrae, S.\&C. Cooper(eds.)Studying Writing: Linguistic approaches[M].Beverly Hills, CA: Sage.

[4] Van Dijk, T.A. 1988 (b).News analysis[M].Lawrence Erlbaum Associates.

[5] Metz, William. News writing from lead to " 30 "[M].PrenticeHall,Inc. 1991. 